\title{
Coffee (Coffea sp.) hull waste fermentation with the addition of banana sucker microorganism activator for physical quality of Ruminantia feed
}

\author{
T Karyono $^{1 *}$ and R Novita ${ }^{1}$ \\ ${ }^{1}$ Faculty of Agriculture, Animal Husbandry Study Program, Musi Rawas University \\ *Corresponding author: teguhkaryono89@gmail.com
}

\begin{abstract}
This research aims to determine the physical quality of coffee hull waste fermentation using a banana sucker microorganism activator. It aims to determine the best composition of banana sucker local microorganism (MOL) activator. Method used in this research was complete randomized design consisting of 6 levels and 4 replications which are, $\mathrm{F} 1=10 \mathrm{ml}$ MOL $/ 1 \mathrm{~kg}$ coffee hull, F2 = $15 \mathrm{ml} \mathrm{MOL} / 1 \mathrm{~kg}$ coffee hull, F3 = $20 \mathrm{ml} \mathrm{MOL} / 1$ $\mathrm{kg}$ coffee hull, F4 $=25 \mathrm{ml} \mathrm{MOL} / 1 \mathrm{~kg}$ coffee hull, F5 = $30 \mathrm{ml} \mathrm{MOL} / 1 \mathrm{~kg}$ coffee hull, F6 = 35 $\mathrm{ml}$ MOL / $1 \mathrm{~kg}$ coffee hull. Silage fermentation physical characteristics observed are acidity/PH, aroma/smell, color, and texture. These characteristics were examined in this research to determine the effect of treatment. The data obtained were analyzed by analysis of variance and further HSD test. The results of the research that the addition of banana sucker microorganism activator to the fermentation of coffee hull waste (coffea sp) on physical quality for ruminant feed showed no significant effect $(\mathrm{P}>0.05) \mathrm{on} \mathrm{pH}$, color, and texture and had a very significant effect $(\mathrm{P}<0,01)$ on the aroma. It can be concluded that the addition of banana sucker microorganism activator in the fermentation of coffee hull gave the best aroma results in the F4 treatment (3.29) and gave equally good results on physical properties such as $\mathrm{pH}$, color, and texture of the fermented coffee hull.
\end{abstract}

\section{Introduction}

Indonesia is an agricultural country in a tropical climate with considerable agricultural, farm, and livestock resources. The main products of those resources are for consumption. Simultaneously, the resulting waste can be utilized as animal feed because animal feed availability is essential for livestock productivity. The growing ruminants population causes more feed needed.

The production of forage fluctuates wildly, it is abundant in the rainy season, but there is a shortage in the dry season in cattle-dense areas. Breeders are facing problems with reducing quality feed sources because one of them is land conversion. The provision of sustainable feed with adequate quality and quantity is one of the determining factors for a livestock business's success. An efficient feeding strategy is to utilize abundant local resources and nutritional value for livestock, especially from agricultural and farm plantation waste. One of the potential agricultural waste used as animal feed is coffee hull waste.

Coffee hulls are one of the agricultural wastes that have been underutilized and just wasted in coffee mills, even though they could potentially become animal feed. The ratio of coffee hull to coffee bean content is $48: 52$. Of the $48 \%$ content of coffee hulls, $42 \%$ are in fruit skins and $6 \%$ of seed skins (horn skin) [1] From the nutritional content evaluation, the dry skin shell contains reducing sugar, non- 
reducing sugar, and pectate compound respectively $12.4 \% ; 2.02 \%$ and $6.52 \%$ and $10.7 \%$ crude protein and $20.8 \%$ crude fiber [2]. Furthermore, the nutritional content in the coffee fruit's skin, such as; crude protein was $10.4 \%$, crude fiber was $17.2 \%$, and metabolic energy was $14.34 \mathrm{MJ} / \mathrm{kg}$ [3]. The optimal use of economically accessible animal feed sources by utilizing local resources, especially coffee hulls available in the local environment, is used as an alternative feed using the fermentation method. It will provide added value for the farmers and improve breeders' easiness of providing feed while reducing the environmental pollution.

Fermentation is the necessary process for converting a material into another in a simple way with microbes' help. Fermented feed ingredients can increase their nutritional value compared to their original ingredients because the principle of fermentation is to activate the growth of microorganisms needed to form new products that are different from the original material. The addition of a microbial starter to coffee hulls is one of the fermentation techniques for processing agricultural and plantation waste to be used as animal feed. Microbes widely used in the fermentation process include yeast, molds, and bacteria Suci. (2008). These microbes can be found in the production of local microorganisms (MOL). According to [4] local microorganism (MOL) is a fermented solution made from various media from available resources. In order to increase the nutrient elements and the breakdown of a material, it is necessary to add an activator such as MOL banana sucker, which can be used as a source of microorganisms that decompose organic matter. [5] This MOL solution contains bacteria and fungi that have the potential to decompose organic matter. The main advantage of using MOL is that it is affordable because it utilizes local ingredients that are around us and is accessible in the manufacturing process, and it is applicable. One of the ingredients that can be used as a MOL solution is a banana sucker activator.

Activators are substances that cause enzyme action [6] So the activator is an additional material that can increase the microbiological breakdown in organic material. According to [7] there are two types of activators: organic and inorganic activators. Organic activators are materials that contain high $\mathrm{N}$ in various forms, such as protein and amino acids. Some examples of organic activators are fungi and soil rich in humus and banana suckers MOL. Inorganic activators include ammonium sulfate, urea, ammonia, and sodium nitrate.

According to [8] banana suckers have microbes that decompose organic matter. These decomposing microbes are live on the outer and inner banana suckers. The types of microbes that have been identified in the MOL of banana suckers include Azospirillium, Azotobacter, Bacillus, Aeromonas, Aspergillus, phosphate solvent microbes, and cellulosic microbes. These microbes usually break down organic matter. We hope to find microbes in the MOL solution of banana suckers that increase nutritional value and reduce the anti-nutritional content found in the coffee hull.

In the fermentation process, to increase nutritional value and reduce crude fiber and accelerate the fermentation process, it is necessary to add activators such as banana suckers MOL. Examining the coffee hull silage fermentation quality can be observed in the coffee hull silage's physical quality.

Based on the preceding, it is necessary to conduct research to overcome agricultural waste by utilizing fermented coffee hull (Coffea $s p$ ) waste with banana sucker MOL as a ruminant animal feed.

\section{Methods}

\subsection{Place and time}

This research was conducted in the nutrition and animal feed laboratory of the Animal Husbandry Study Program, Faculty of Agriculture, Musi Rawas University. Implementation was carried out from May to July 2020.

\subsection{Materials and Tools}

The materials used in this study were coffee hull waste, banana suckers MOL, which was given according to the treatment level. 
The tools used in this research are 24 plastic bags @ $10 \mathrm{~kg}$, large knives, plastic labels, hoses, jerry cans, sprayers and buckets, digital and analog scales, space thermometers, markers, and $\mathrm{pH}$ meters. This research uses the method experimental with a completely randomized design (CRD) consisting of 6 treatments F1 $=1 \mathrm{~kg}$ coffee hull $+10 \mathrm{ml}$ MOL banana suckers, $\mathrm{F} 2=1 \mathrm{~kg}$ coffee hull $+15 \mathrm{ml}$ banana weevil MOL, F3 $=1 \mathrm{~kg}$ coffee hulls $+20 \mathrm{ml}$ MOL weevil banana, F4 = $1 \mathrm{~kg}$ coffee hulls $+25 \mathrm{ml}$ Banana head mol, F5 = $1 \mathrm{~kg}$ coffee hulls $+30 \mathrm{ml}$ Banana suckers MOL, F6 $=1 \mathrm{~kg}$ coffee hulls +35 $\mathrm{ml}$ Banana suckers MOL. Each treatment was repeated four times so that we get 24 experimental units.

\subsection{Research procedure}

\subsubsection{The first stage: Making $M O L$}

This research begins with the preparation of the banana suckers MOL culture media. The materials are: $1 \mathrm{~kg}$ banana suckers, $0.25 \mathrm{~kg}$ of brown sugar, and 2 liters of coconut water are prepared in advance. The stages of manufacture are:

1. Slice bananas suckers thinly then pounded.

2. Slice Brown sugar thinly to make it easier to dissolve with coconut water.

3. Put the banana suckers, brown sugar, and coconut water into a bucket, then stir until evenly distributed.

4. All the mixed ingredients in a bucket are then put into a 5-liter jerry can, with a hole on the lid and a small tube connected to the used mineral water bottle to remove the residual gas from the fermentation process, then fermented for 15 days. [9]

\subsubsection{Second stage: Physical Test}

The observed physical test consists of $\mathrm{pH}$, odor/aroma, color, and texture of the resulting coffee hull fermentation. For the physical test (odor/aroma, color, texture) is done by using the numbers (scores) that have been determined by [10] procedure. In this physical test, panelists of 11 people observing the physical form of a compost sample of 200 grams on the plastic mat at the table. PH observations were carried out at the beginning and end of the fermentation process of coffee hull. $\mathrm{PH}$ measurement refers to [11] procedure, using a $\mathrm{pH}$ meter (digital), coffee hull weighed 10 grams, and add $100 \mathrm{ml}$ of distilled water was deposited for 15 minutes. Then the $\mathrm{pH}$ was measured and recorded.

\section{Results and Discussion}

\subsection{Degree of acidity $(\mathrm{pH})$}

The acidity level in the fermentation process is an essential factor in the silage fermentation process. The decrease in $\mathrm{pH}$ indicates the activity of microorganisms in the fermentation process of coffee hull silage. Table 1 shows the $\mathrm{pH}$ average of coffee hull silage fermentation. The analysis results show that the fermentation of coffee hull with banana suckers MOL has no significant effect on the $\mathrm{pH}$ of coffee hull fermentation. From observations of coffee hull fermentation $\mathrm{pH}$, an average range of $\mathrm{pH}$ is 3.94 to by 4.08. This resulting $\mathrm{pH}$ classified as excellent silage category, according to [12] that the quality of silage can be categorized based on its $\mathrm{pH}$, namely: 3.5-4.2 excellent, 4.2- 4.5 is good, 4.5-4.8 is moderate, and more than 4.8 is bad. Furthermore, [13] stated that silage's acidity level is an essential criterion as the primary assessment of making silage success. Acidic conditions will prevent the forage from being decomposed by destructive or rotting microbes and the level of palatability of livestock.

Based on the study's initial $\mathrm{pH}$ test, the average $\mathrm{pH}$ value ranged from 5.59 to 5.92 , and at the end of the study, the final $\mathrm{pH}$ value was 3.94 to 4.08 . This decrease in $\mathrm{pH}$ value is due to the composition of the main ingredients in making silage, namely coffee hulls and banana suckers MOL as bio activators work very well to spur microbes such as lactic acid bacteria (LAB) during the ensilage process. Lactic acid produced during the ensilage process will act as a preservative to prevent 
the growth of rotting microorganisms. [14] stated that the acids produced during the ensilage are lactic acid (Lactobacillus lactis, Lactobacillus bulgaricus, Lactobacillus achidophilus, Lactobacillus casei, Lactobacillus plantarum, Lactobacillus achidophilus, Lactobacillus casei, Lactobacillus plantarum, Lactob Bifidobacterium bifidum, Pediococcus or Streptococcusn and Acetobacter aceti), propionate, formicate, succinate and butyrate.

Fermentation begins when materials in making silage fermentation use up all the oxygen. In this study, the materials used are coffee hull waste. Bacteria use soluble carbohydrates to produce lactic acid to reduce silage $\mathrm{pH}$. The decrease in $\mathrm{pH}$ value can also be caused by microbial activity, increasing the acid content in the material's silage so that the $\mathrm{pH}$ becomes decreased. This acidic state is caused by ethanol's oxidation to acetaldehyde, which is then oxidized to lactic acid. This condition will cause the environment to become acidic. This condition corresponds to [15] opinion that the silage fermentation's acidic state is caused by the oxidation of ethanol to acetaldehyde, which then undergoes further oxidation to become lactic acid. [16] also added that the more carbohydrates that are broken down into glucose, acetic acid, alcohol, and other compounds, the acidic environment will be quickly obtained.

\subsection{Smell /Aroma}

The analysis of variance and tabulation data in the study of fermentation of coffee hulls with banana suckers MOL showed a significant effect on the fermentation of coffee hulls silage. The HSD test results show that the F4 treatment is very significantly different from F5 and F6, and is significantly different from F2 and F3, and is not significantly different from F1. We presume this result is due to the different treatment in giving banana suckers Mol to the coffee hull's fermentation to produce a very significantly different smell/aroma. The results of observations on the smell/aroma of coffee hulls silage are listed in Table 1.

The coffee hull silage observation showed that the highest odor or aroma was F4 (3.29), and the lowest smell or aroma of silage was F6 (1.74). In treatment F4 (3.29), F3 (3.26), F2 (3.13), and F1 (3.08) produced a fresh sour aroma, fermented aroma (ring score 3) and included in the excellent silage category, while in treatment F5 (1.98) and F6 (1.74) produced a slightly sour smell (ring score 2). The activity of bacteria that produce acid is causing the sour smell/aroma. This condition corresponds to the opinion of [17] which states that in the anaerobic process of making silage, anaerobic bacteria are actively working to produce organic acids making a sour smell produced by silage.

A very significant difference in the odor/aroma of coffee hulls silage ferments with banana suckers MOL. The sour smell indicates that the silage fermentation resulting from anaerobic bacteria actively works to produce organic acids, which emit an acidic odor in the silage. As a result of the activity of these bacteria, an acidic condition occurs in the silage. According to opinion [18], in the ensilage process, when oxygen is all used up, breathing will stop, and the atmosphere becomes anaerobic, and the acidic conditions of the material begin to work. In this condition, the fungus cannot grow, and only bacteria are still active especially acid-forming bacteria. Thus, the sour smell can be used as an indicator to see the success of the ensilage process because it must be in an acidic atmosphere for the success of the ensilage process. According to [19] good silage has a sour aroma and remains fresh and smells like fermentation.

\subsection{Color}

Table 1 shows the results of observations on the smell/aroma of compost. The results of the analysis of variance showed that the fermentation of coffee hull silage with banana suckers MOL as ruminant animal feed had no significant effect on the silage color with the experimental parameters. From the observations, all the resulting silage fermentation is brownish-black with an average ring score of 3 . This resulting color shows that the fermentation of coffee hull silage with banana suckers MOL produces silage just as good in terms of color. The results of the silage of coffee hulls with banana suckers MOL are right, namely brownish-black, because the results of good silage will be brownish- 
black evenly on all sides. This resulting color follows [17], which states that in general good silage has color characteristics like the original material, such as boiled leaves or dark brown for rice straw silage.

The color of the fermentation that is not significantly different from this study results is also due to coffee hull waste as the material, which tends to be brownish-black. This material corresponds to [20] opinion explaining that it is necessary to consider several vital aspects that will support the making and availability of silage in the silage fermentation process. These aspects include the availability of materials, materials used, price, and fermentation media in making silage, which are the most important determining factors for microbial growth.

Tabel 1. Analysis of Fermentation Variety of Coffee hull Waste Using Banana Suckers MOL As Ruminant Animal Feed

\begin{tabular}{llll}
\hline No & Parameter & Banana Sucker & MOL \\
Treatment & CV $(\%)$ \\
\hline 1. & $\mathrm{pH}$ & $1.39^{\mathrm{tn}}$ & $2,18 \%$ \\
2. & Aroma & $55.95^{* *}$ & $6,91 \%$ \\
3. & Color & $1.94^{\mathrm{tn}}$ & $13.60 \%$ \\
4. & Texture & $1,48^{\mathrm{tn}}$ & $11,55 \%$ \\
\hline
\end{tabular}

Information: CV: Coefficient of variation, tn: Not Significant, ${ }^{* *}$ :Very Significant

Tabel 2. Observation Parameter Value of Coffee hull Waste Fermentation Using Banana Suckers MOL as Animal Feed

\begin{tabular}{|c|c|c|c|c|c|c|c|c|}
\hline \multirow[t]{2}{*}{ Treatment } & \multicolumn{6}{|c|}{ Parameter } & \multicolumn{2}{|c|}{ HSD value } \\
\hline & $\mathrm{F} 1$ & $\mathrm{~F} 2$ & F3 & F4 & F5 & F6 & $5 \%$ & $1 \%$ \\
\hline $\mathrm{pH}$ & $4,08 \pm 0.06$ & $4,01 \pm 0,05$ & $4,05 \pm 0,05$ & $3,98 \pm 0,10$ & $3,99 \pm 0,14$ & $3,94 \pm 0,08$ & & \\
\hline Aroma & $3,08^{\mathrm{bB}} \pm 0,26$ & $3,13^{\mathrm{bB}} \pm 0,23$ & $3,26^{\mathrm{bB}} \pm 0,24$ & $3,29^{\mathrm{bB}} \pm 0,17$ & $1,93^{\mathrm{aA}} \pm 0,06$ & $1,74^{\mathrm{aA}} \pm 0,05$ & 0,046 & 0,058 \\
\hline Color & $2,77 \pm 0,35$ & $3,04 \pm 0,42$ & $3,07 \pm 0,27$ & $3,04 \pm 0,55$ & $3,38 \pm 0,45$ & $2,56 \pm 0,33$ & & \\
\hline Texture & $2,12 \pm 0,29$ & $2,25 \pm 0,34$ & $2,03 . \pm 0,14$ & $2,04 \pm 0,18$ & $2,32 \pm 0,28$ & $1,922 . \pm 0,15$ & & \\
\hline
\end{tabular}

Information: The numbers followed by different letters on the same line mean that they are not significantly different at the HSD test levels of 5\% and 1\%. 3 (fresh sour aroma), color 2 (brownish black), texture 2 (slightly soft).

\subsection{Texture}

Table 1 shows the results of observations on the texture of coffee hull fermentation with banana suckers MOL. The analysis of variance and tabulation data on the fermentation of coffee hulls silage with banana suckers MOL shows no significant effect on the texture of coffee hulls silage fermentation. Because the composition of the silage material is coffee hulls waste, which has almost the same size and shapes, the decomposition of the material by microorganisms was as good as all experimental parameters. Furthermore, the resulting silage texture is in the medium category (not too hard). The texture of the coffee hulls silage results from the study can be categorized as good because it is close to the original texture. This resulting texture is per [18] In general, good silage has texture characteristics still like the original material. Furthermore, [19] explained that good quality silage has a fresh texture like the original material and preferable by livestock.

The texture of coffee hulls silage fermentation on all parameters showed no significant difference because the effect of microbes acting on all silage materials can adequately react. According to [21] opinion, hemicellulase acid hydrolysis is a chemical reaction that breaks down cellulose in plant cell walls (coffee hulls) caused by interactions with hydrogen ions in the fermentation of silage materials. Furthermore, during the ensilage, microorganism activity degrades cellulose and hemicellulose components in the silage fermentation process. 


\section{Conclusion}

The results of the research on fermentation of coffee hull waste (Coffea $\mathrm{sp}$ ) with the addition of banana weevil mole activator on physical quality for ruminant animal feed, It can be concluded that the addition of banana weevil MOL activator in the fermentation of coffee peels gave the best aroma results in the F4 treatment (3.29) and gave equally good results on physical properties such as: $\mathrm{pH}$, color and texture of the fermented coffee skin.

\section{References}

[1] Suci, L. 2008. Pemanfaatan Kulit Kopi Arabika Dari Proses Pulping Untuk Pembuatan Etanol. Jurnal Reaksi ( Journal of Science and Tecnology). Jurusan Teknik Kimia Politeknik Negri Lhoksumawe. Vol 10 (21). ISSN 1693-248X.

[2] Widyotomo, S. (2013). Potensi dan Teknologi Diversifikasi Limbah Kopi Menjadi Produk Bermutu dan Bernilai Tambah. Review Penelitian Kopi Dan Kakao, 1(1), 63-80.

[3] Simanihuruk..K. dan J.Sirait.2010. Silase Kulit Buah Kopi Sebagai Pakan Dasar Pada Kambing Boerka Sedang Tumbuh. Seminar Nasional Teknologi Peternakan dan Veteriner 2010

[5] Karyono.T dan J.Laksono. 2019. Kualitas Feses sapi potong dan Kulit Kopi dengan Penambahan Aktivator Mol Bongkol Pisang dan EM4. Jurnal Peternakan Indonesia. Vol.21(2): 154-162

[6] Rifa'i, Mien.A. 2004. Kamus biologi. Cetakan ke-4. Balai Pustaka Jakarta.halaman 11

[8] Moses B.B.O, A. Wibowo. Jati, B. B. Rahardjo Si. 2013. Pengunaan Mikroorganisme Bongkol Pisang (Musa paradisiaca) Sebagai Dekomposer Sampah Organik.Jurnal Teknobiologi Universitas AtmaJaya Yogyakarta

[9] Karyono.T, Maksudi dan Yatno.2017. Penambahan Aktivator Mol Bongkol Pisang dan EM4 dalam Campuran Feses Sapi Potong dan Kulit Kopi terhadap Kualitas Kompos dan Hasil Panen Pertama Rumput Setaria. Jurnal Sain Peternakan Indonesia.Vol.12 (1) : 102 - 111.

[12] Mirni L, Ismudiono, Koesnoto S, Sri Chusniati, Nanik Hidayatik, Vina E.V.F. 2012. Karakteristik silase pucuk tebu (saccharum officinarum, linn) dengan penambahan lactobacillus plantarum. Departemen Peternakan, Departemen Reproduksi Veteriner,Departemen Mikrobiologi Veteriner Fakultas Kedokteran Hewan Universitas Airlangga. Agroveteriner 1(1), Desember 2012

[13] Ridwan, R, S. Ratnakomala, Kartina, G dan Widyastuti, Y., 2005. Pengaruh Penambahan Dedak Padi dan Lactobacillus planlarum 1BL-2 dalam Pembuatan Silase Rumput Gajah (Pennisetum purpureum). Media Peternakan. Vol 28 No.3 hal: $117-123$

[14] Mugiawati R.E., Suwarno dan Hidayat, N. 2013. Kadar Air dan pH Silase Rumput Gajah Pada Hari Ke-21 dengan Penambahan Jenis Additive dan Bakteri Asam Lakat. Jurnal Ilmiah Peternakan. 1(1):201-207.

[15] Sebayang, F. 2006. Pembuatan Etanol dari Molases Secara Fermentasi Menggunakan Sel Saccharomyces cerevisiae yang Terimobilisasi pada Kalsium Alginat. Jurnal Teknologi Proses 5 (2) $75-80$.

[16] Simbolon, K. 2008. Pengaruh Persentase Ragi Tape dan Lama Fermentasi Terhadap Mutu Tape Ubi Jalar. Departemen Teknologi Pertanian, Fakultas Pertanian, Universitas Sumatera Utara

[17] Lamid, M., Ismudiono., Koesnoto., S. Chusniati., N. Hidayatik., dan Vina E. V. F. 2012.Karakteristik silase pucuk tebu (Saccharum officinarum, Linn) dengan penambahan Lactobacillus plantarum. Agroveteriner 1 (1): 5-10.

[18] Herlianie.2015. Karakteristik Fisik Silase Campuran Daun Ubikayu (Manihot esculenta) dan Rumput Kumpai (Hymenachine ampleexicaulis). Jurnal Ilmu Hewani Tropika 4( 2). Fakultas Peternakan Universitas Kristen Palangka Raya. Desember 2015.

[19] Kurnianingtyas, I. B., P. R. Pandansari., I. Astuti., S. D. Widyawati., dan W. P. S. Suprayogi. 2012. Pengaruh macam akselerator terhadap kualitas fisik, kimiawi, dan biologis silase rumput kolonjono. Tropical Animal Husbandry 1 (1): 7-14. 
[20] Kushartono, B. dan Iriani, N. 2005. Silase Tanaman Jagung Sebagai Pengembangan Sumber Pakan Ternak . Prosiding Temu Teknis Nasional Tenaga Fungsional Pertanian.Bogor : Balai Penelitian Ternak

[21] Ratnakomala, S., R. Ridwan, G. Kartina, \& Y. Widyatuti. 2006. Pengaruh inoculum Lactobacillus plantarum 1A-2 dan 1BL-2 terhadap kualitas silase rumput gajah (Pennisetum purpureum). Biodivertas. 7: 131-134 